Pleione 14(2): 249 - 253. 2020.

(C) East Himalayan Society for Spermatophyte Taxonomy

doi:10.26679/Pleione.14.2.2020.249-253

\title{
Anthoxanthum monticola (Bigelow) Veldkamp [Poaceae]: A new record for India
}

\author{
Manish K. Kandwal ${ }^{1,4}$, Sandeep Tambe ${ }^{2}$ and G. S. Rawat ${ }^{3}$ \\ ${ }^{1}$ Botanical Survey of India, Botanic Garden of Indian Republic, Noida 201303 Uttar Pradesh, India \\ ${ }^{2}$ Indian institute of Forest management, Bhopal 462003, Madhya Pradesh, India \\ ${ }^{3}$ Wildlife Institute of India, Chandrabani, Dehradun, 248001, Uttarakhand, India \\ ${ }^{4}$ Communicating author,e-Mail: zoysia04@gmail.com
}

\begin{abstract}
Anthoxanthum monticola (Bigelow) Veldkamp, (Poaceae), an alpine grass is reported here for the first time from two different localities in India. A detailed description, key to species in India, illustration, and photographs are provided for easy identification of the species.
\end{abstract}

Key words: Anthoxanthum, Hierochloe, Poaceae, Arunachal Pradesh, Sikkim, India, New record

The genus Anthoxanthum L. of the tribe Aveneae Dumort of Poaceae, characterized by coumarin scented plants, is represented by about 50 species in the world ( $\mathrm{Zu}$ et al. 2006). It is distributed worldwide especially in temperate and alpine meadows, open grasslands and marshy places (Clayton \& Renvoize 1986; Zu et al. 2006). In India the genus is represented by 8 species, vir;, A. borii Jain \& $\mathrm{Pal}, A$. clarkei (Hook.f.) Ohwi, A. hookeri (Griseb.) Rendle, $A$. sik.kimmense (Maxim.) Ohwi and $A$. odoratum L., $A$. khasianum (C.B. Clarke) Ohwi, A. laxum (Hook.f.) Veldkamp, $A$. flexuosum (Hook.f.) Veldkamp. Anthoxanthum borii is endemic to South India while A. odoartum is an introduced species, also found as an escape. The other six species are distributed all along the Himalayan region (Mitra 1958; Bor 1960; Karthikeyan et al. 1989).

The genus Anthoxanthum has been separated from Hierocblö̈ R.Br. by having two basal sterile, epaleate and geniculately awned lower florets. The genus Hierocloe is characterized by the absence of lodicules, presence of stamens in two lower florets, presence of palea and short awns or sometimes awnless. However, a number of species are intermediate in these characters ( $\mathrm{Zu}$ et al. 2006) where the sex of the lower florets is variable within the species. Hierocbloe has been treated as a separate genus by previous workers in India (Bor 1960; Karthikeyan et al. 1989; Shukla 1996; Clayton et al. 2006; Kandwal \& Gupta 2009).

During the exploration of grasses in the Himalayan region, the authors came across some interesting specimens collected from two different localities in the Eastern Himalaya. Critical study of the specimens followed by scrutiny of literature (Bor 1960; Clayton \& Renvoize 1986; Shukla 1996; Zu et al. 2006) reveals that they belong to genus Anthoxanthum. On further study, these specimens were identified as Anthoxanthum monticola. It is a dwarf species characterized by $4-7 \mathrm{~mm}$ long awn on second bifid lemma, and $3 \mathrm{~mm}$ long awn on first lemma. The species, is so far reported from alpine meadows of China, Japan, Korea, Mongolia, Russia, North Europe and North America (Clayton et al. 2006; Zu et al. 2006). It is not recorded from India (Hooker 1897; Bor 1940, 1960; Hara 1966, 1971; Deb 1983; Shukla 1996; Noltie 2000; Chowdhery et al. 2009; Kandwal \& Gupta 2009). Hence it is reported here for the first time from India along with its key to species found in India, description, field photo and illustration to aid identification in the field (Figures $1 \& 2$ ). 


\section{Key to the species in India (including Hierochloe):}

1a. Lower floret both sterile, epaleate (Anthoxanthum) ................................................... 2

1b. Lower floret staminate, paleate (Hierochloe) .......................................................... 6

2a. Perennial; upper glume mucronate; anthers $3 \ldots \ldots \ldots \ldots \ldots \ldots \ldots \ldots \ldots \ldots \ldots \ldots \ldots \ldots$. sikkimense

2b. Annual; upper glume not mucronate; anthers 2 ( 3 in $A$.borii $)$................................. 3

3a. Leaves non aromatic; lower glume elliptic ........................................................... hookeri

3b. Leaves aromatic; lower glumes lanceolate or oblong ............................................... 4

4a. Rhizome absent; awns of the spikelets projecting $2 \mathrm{~mm}$ or less beyond the tip of the spikelets

A. odoratum

4b. Rhizome elongated; awn projection much more than $2 \mathrm{~mm}$ beyond the tip of the spikelet ...5

5a. Inflorescence contracted, lanceolate to oblong; leaves linear lanceolate, up to $10 \mathrm{~mm}$ broad, spikelet $6.5 \mathrm{~mm}$ long, on short hairy pedicels; second lemma awned from the back, $5 \mathrm{~mm}$ long; third lemma $3 \mathrm{~mm}$ long

A. borii

5b.Inflorescence spiciform; leaves linear, up to $5 \mathrm{~mm}$ broad; spikelet $5.5 \mathrm{~mm}$ long, on glabrous pedicels; second lemma $5.5 \mathrm{~mm}$ long; third lemma $3.5 \mathrm{mmlong}$

A. clarkie

6a. Spikelet 3 -3.5 mm long; basal floret barren without signifant palea

A. khasianum

6b. Spikelet 4-7 $\mathrm{mm}$ long; basal floret male with palea

7a. Inflorescence contracted; leaves less than $2 \mathrm{~mm}$ wide; basal floret dissimilar

A. monticola

7b. Inflorescence lax; leaves more than $2 \mathrm{~mm}$ wide

8

8a. Rhizome present, elongate; leaves aromatic, glumes gaping

A. laxum

8b. Rhizome absent, leaves non aromatic, glumes parallel

A. flexuosum

Anthoxanthum monticola (Bigelow) Veldkamp, Blumea 30: 347. 1985; Zu et al, in Fl. China, Poaceae. 22: 338. 2006. Holcus monticola Bigelow, New Engl. J. Med. \& Surg. 5: 334.1896; Hierochloe alpina (Sw. ex Willd.) Roem. \& Schult., Syst. Veg. 2: 515. 1817. Holcus alpinus Sw. ex Willd., Sp. Pl., ed.4 [Willdenow] 4(2): 937. 1806.

Rhizomatous perennials, rhizomes short. Culms solitary or few, erect, $20-40 \mathrm{~cm}$ tall. Leaf-sheaths glabrous on surface, striate, longer than or equal to internodes. Ligules aciliate and membranous, $1-2 \mathrm{~mm}$ long. Leaf blades flat, $10-25 \mathrm{~cm}$ long, $1-4 \mathrm{~mm}$ wide, aromatic. Lamina glabrous or minutely scabrous. Inflorescence a contracted panicle, oblong or ovate in outline, $3-6 \mathrm{~cm}$ long, $1-2 \mathrm{~cm}$ wide with short branches, sometimes nodding. Spikelets 3-flowered, solitary, pedicelate, oblong, laterally compressed, $5-6 \mathrm{~mm}$ long; 2 basal florets sterile, 1 upper floret fertile, rhachilla not produced. Glumes $5-6 \mathrm{~mm}$ long, subequal, as long as spikelet, thinner than fertile lemma. Lower glumes ovate, $5-6 \mathrm{~mm}$ long, membranous,3-nerved, 1-keeled, apex acute. Upper glume ovate, $5-6 \mathrm{~mm}$ long, membranous, 3-nerved,1-keeled, apex acute. Basal sterile florets dissimilar; male florets paleate. Lower lemma elliptic, $5 \mathrm{~mm}$ long, chartaceous, 1-keeled, 5-nerved, pubescent, dentate, 2-fid, awned, margins and keel hairy; awn $1-3 \mathrm{~mm}$ long. Palea, linear, ca $4 \mathrm{~mm}$ long, 2nerved, 2-fid, 2-keeled, keels hairy on upper half. Second lemma oblong, equal to lower lemma in size, chartaceous, pubescent,2-lobed, obtuse, margins and keels hairy, awned. Awn weakly geniculate, scabrid, $5-7 \mathrm{~mm}$ long. Palea similar to palea of lower lemma. Fertile (upper) lemma ovate, ca $4 \mathrm{~mm}$ long, cartilaginous, without keel. Surface densely hairy above, margins convolute, apex acute. Palea elliptic, 1-nerved, without keels. Anthers 2, or 3, $1.5-$ $2 \mathrm{~mm}$ long. Ovary glabrous.

Flowering \& Fruiting: June - August.

Habitat: Alpine moist meadows, 3000 - $4500 \mathrm{~m}$.

Distribution: India (Eastern Himalaya); NE China, Japan, Korea, Mongolia, Russia, North Europe, North America. 

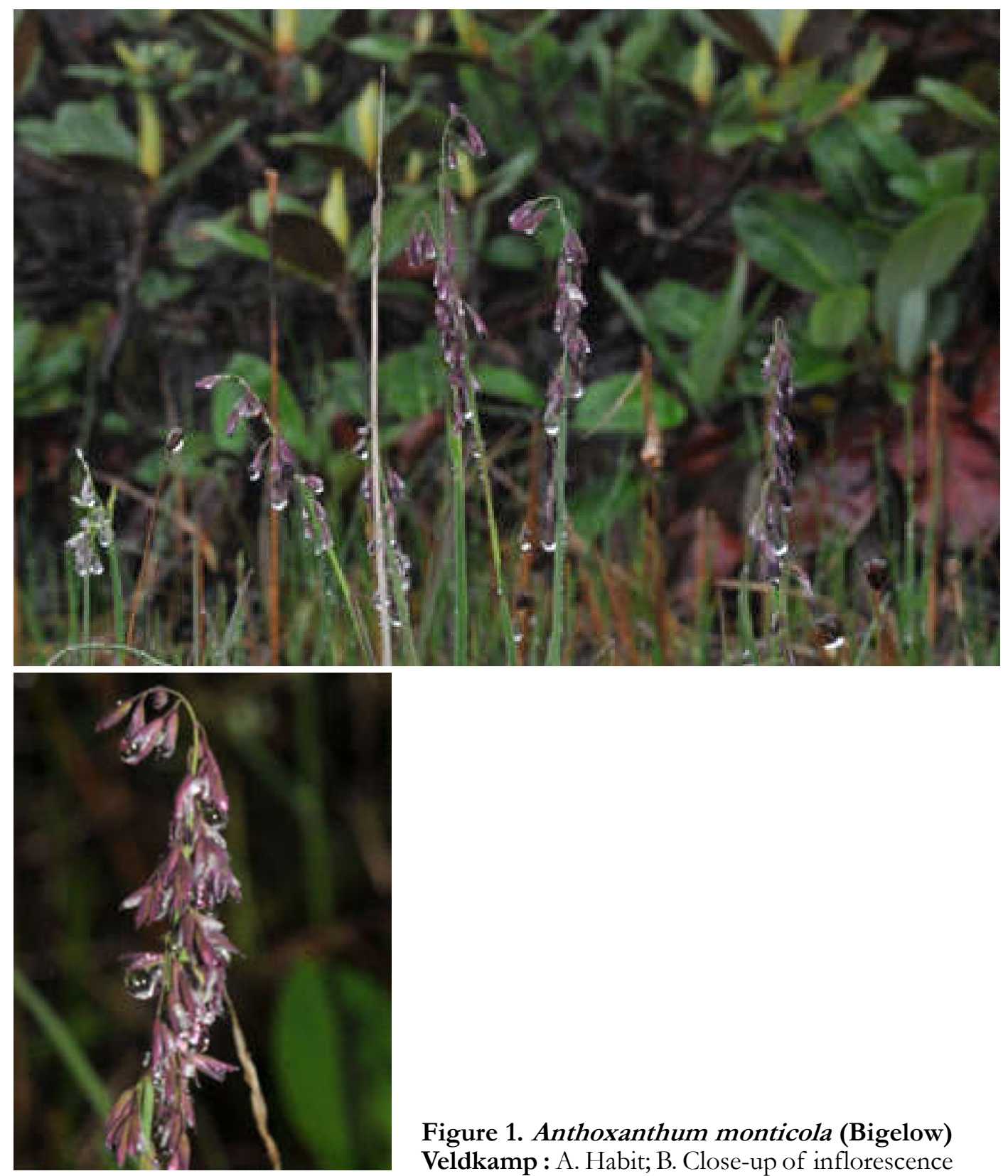

Figure 1. Anthoxanthum monticola (Bigelow)

Veldkamp : A. Habit; B. Close-up of inflorescence

Specimens examined: India: Arunachal Pradesh, Tawang District, PT Tso lake, 9 July 2012, M. K. Kandwal 37148 (ARUN); Sangester Lake, 3000 m,9 July 2012, M. K. Kandwal 37147 (ARUN). Sikkim, Khangchendzonga National Park, Arralongchak area, 4150 m, 26.07. 2005, Sandeep Tambe 32483 (WII).

\section{Acknowledgements}

Senior author (MKK) is grateful to the Director, Botanical Survey of India, Kolkata for providing necessary facilities during the present work and to the Indian Army, Indian Tibet border police and district authorities of Tawang district, Arunachal Pradesh for providing logistic support during the exploration work in the state. 


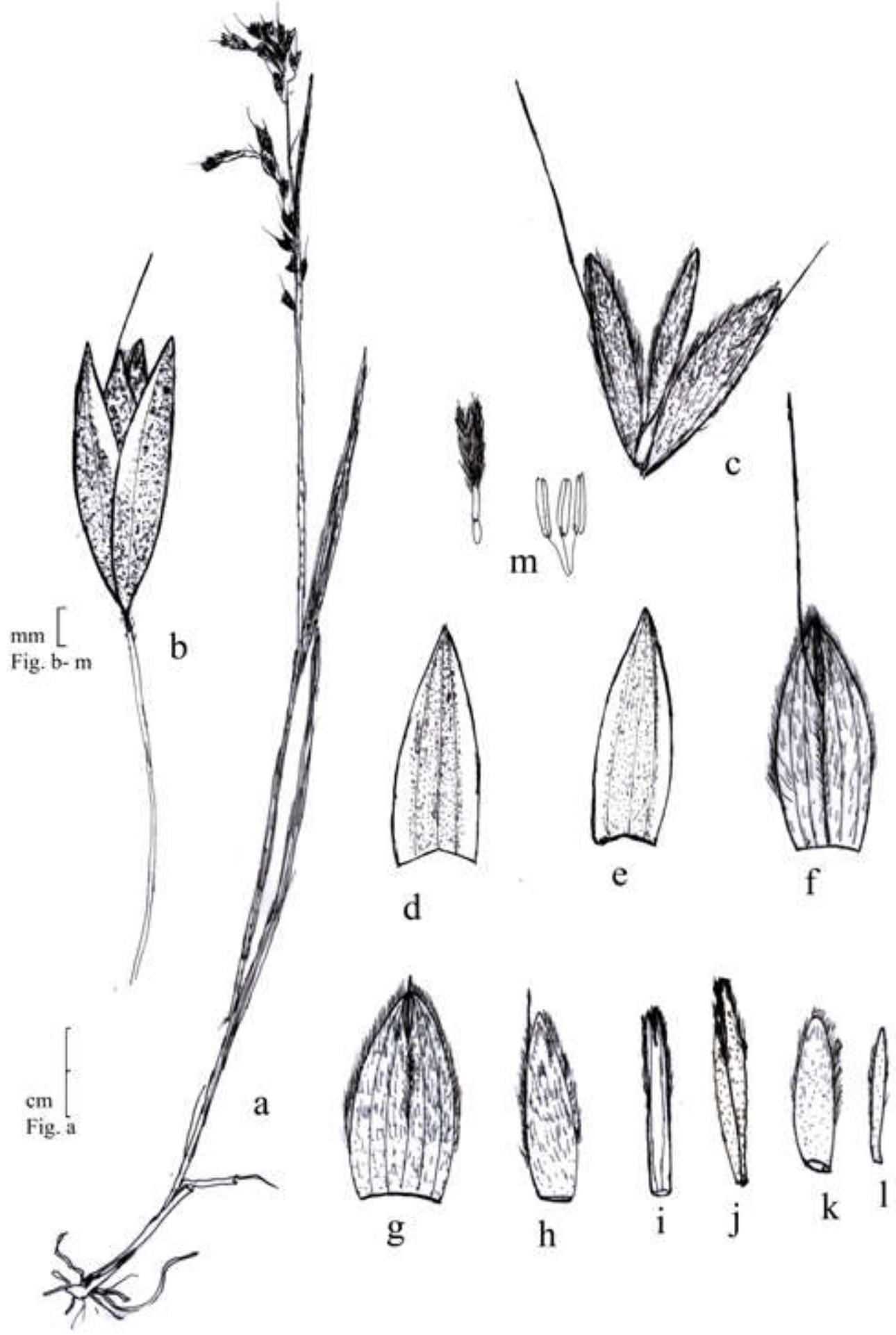

Figure 2. Anthoxanthum monticola (Bigelow) Veldkamp: a. Habit; b. Spikelets; c. Floret; d. Lower glume; e. Upper glume; f. Second lemma; g. - h. Second lemma (Dorsal and sideview); i - j. Palea of first lemma; k. Third lemma; 1 . Palea of third lemma; m. Stamens and pistil. 


\section{LITERATURE CITED}

Bor, N.L.1940. Flora of Assam, Vol. V. Gramineae.Calcutta.

Bor, N.L. 1960. The Grasses of Burma, Ceylon, India and Pakistan. Pergamon Press, London.

Chowdhery, H.J.; Giri, G.S.; Pal, G.D.; Pramanik, A. \& Das, S.K. 2009. Materials for the flora of Arunachal Pradesh (Hydrocharitaceae - Poaceae), Vol. 3. Botanical Survey of India, Kolkata.

Clayton, W.D. \& Renvoize, S.A. 1986.Genera Graminum. HMSO Publications, London.

Clayton, W.D.; Vorontsova, M.S.; Harman, K.T. \& Willioamson, H. (2006 onwards) Grass base - The online world Grass Flora Http://www.Kew.org/data/grasses.

Deb, D.B. 1983. The Flora of Tripura State Vol II (Buddlejaceae-Gramineae). Today and Tomorrow Printers and Publishers. New Delhi.

Hara, H.1966.The Flora of Eastern Himalaya, First Report. The University of Tokyo Press, Japan.

Hara, H. 1971. The Flora of Eastern Himalaya, Second Report. The University of Tokyo Press, Japan.

Hooker, J.D. 1897. Flora of British India, Vol.7. L. Reeve \& Co., London.

Kandwal, M. K. \& Gupta, B.K. 2009. An update to grass flora of Uttarakhand. Ind. Jour. For. 32: $657-668$.

Karthikeyan, S.; Jain, S.K.; Nayar, M.P. \& M. Sanjappa. 1989. Fl. Ind., Enum. - Monocot. Botanical Survey of India, Calcutta, India. .

Mitra, J.N.1958. Flowering plants of Eastern India. Vol. I. Monocotyledons, World press Pvt. Ltd., Calcutta.

Noltie, H.J. 2000. The Grasses of Bhutan In Flora of Bbutan Vol. 3(2). Royal Botanic Garden Edinburg \& Royal Government of Bhutan.

Shukla, U. 1996. Grasses of North-Eastern India. Scientific Publishers, Jodhpur.

Zu Y.M.; Zhenlan, W.; Shenglian, L.; Shou-liang, C.; Wenli C. \& Phillips S.M. 2006. Tribe Aveneae. In: W. Zhengyi, P.H. Raven, H. Deyuan (eds.), Flora of China - Poaceae. Vol. 22. Science Press and Missouri Botanical Garden, Beijing and St. Louis. 